\title{
Nigerasperones A C , New Monomeric and Dimeric Naphtho- $\gamma$-pyrones from a Marine Alga-derived Endophytic Fungus Aspergillus niger EN-13
}

\author{
Yi Zhang, Xiao-Ming Li, Bin-Gui Wang
}

Received: November 6, 2006 / Accepted: March 5, 2007

(C) Japan Antibiotics Research Association

\begin{abstract}
Three new naphtho- $\gamma$-pyrones, 5-hydroxy-6,8dimethoxy-2-hydroxymethyl-4H-naphtho[2,3-b]pyran-4one (1, nigerasperone A), 3,3'-dihydro-2,2',5,5'-tetrahydroxy-8, $8^{\prime}, 10,10^{\prime}$ - tetramethoxy-2,2' -dimethyl-(6',9-bi-4Hnaphtho[1,2-b]pyran)-4,4'-dione (2, nigerasperone $\mathrm{B})$, and $3^{\prime}$-hydro-2',5,5',8-tetrahydroxy-6,6', 8' -trimethoxy-2,2'dimethyl-(7,10'-bi-4H-naphtho[2,3-b]pyran)-4,4'-dione (3, nigerasperone $\mathrm{C}$ ), together with nine related known compounds were characterized from Aspergillus niger EN-13, an endophytic fungus isolated from the marine brown alga Colpomenia sinuosa. Their structures were elucidated by detailed analysis of spectroscopic data and by comparison with literature reports. In the cytotoxic assay, these compounds did not show remarkable inhibitory effects against A549 and SMMC-7721 tumor cell lines. However, 3 and several known compounds showed weak antifungal activity against Candida albicans and moderate activity on DPPH scavenging.
\end{abstract}

Keywords Colpomenia sinuosa, algous endophytic fungus, Aspergillus niger, naphtho- $\gamma$-pyrone

X.-M. Li (Corresponding author), B.-G. Wang (Corresponding author), Y. Zhang: Key Laboratory of Experimental Marine Biology, Institute of Oceanology, Chinese Academy of Sciences, Nanhai Road 7, Qingdao 266071, PR China,

E-mail: wangbg@ms.qdio.ac.cn

Y. Zhang: Graduate School of Chinese Academy of Sciences, Beijing 100049, PR China

\section{Introduction}

The secondary metabolites of the fungal strains of the genus Aspergillus, both terrestrial and marine origin, have been extensively studied. Like other members in this genus, marine isolates of Aspergillus niger have been proven to be prolific source of new secondary metabolites unknown from those of the terrestrial ones. For example, some isolates of $A$. niger from marine sponges and ascidians produced novel metabolites including asperazine, aspernigrins $\mathrm{A}$ and $\mathrm{B}$, yanuthones $\mathrm{A} \sim \mathrm{E}$, nafuredin, and so on [1 4]. In our investigation on bioactive metabolites of marine-derived microorganisms, we isolated a pure strain, morphologically identified as A. niger EN-13, from the inner tissue of the brown alga Colpomenia sinuosa that was collected along the Qingdao coastline. The crude extract of the culture broth showed moderate cytotoxic activity against SMMC-7721 tumor cell line. During the course of chromatographic separation of the methanol and ethyl acetate extracts from the mycelium and broth of the fungus, three new naphtho- $\gamma$-pyrones, which were named as nigerasperones $\mathrm{A} \sim \mathrm{C}(\mathbf{1} \sim \mathbf{3})$, along with nine related known compounds, aurasperones A (4) and B (5) [5], dianhydroaurasperone $\mathrm{C}(6)$ [6], asperpyrones $\mathrm{A}(7)$ and $\mathrm{C}$ (8) [7], and fonsecinones $A \sim D(9 \sim 12)$ [5], were isolated and identified (Fig. 1). We wish to report here the isolation, structural elucidation, and bioassay of these metabolites from A. niger EN-13. 


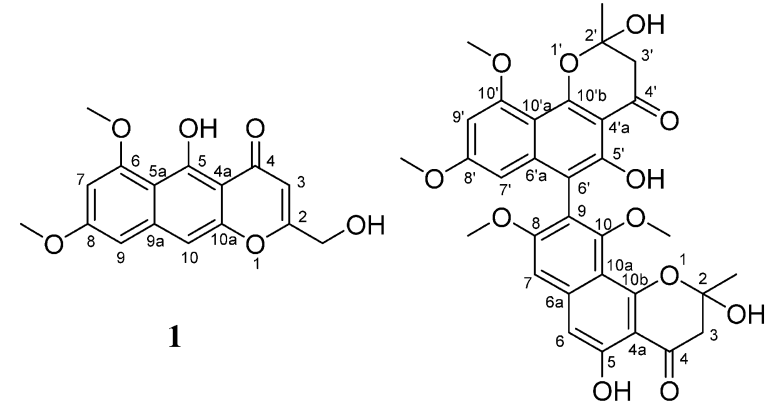

2

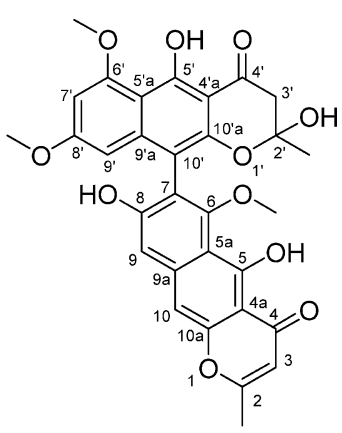

3

Fig. 1 Structures of nigerasperones $A \sim C(\mathbf{1} \sim \mathbf{3})$.

\section{Materials and Methods}

\section{General Experimental Procedure}

Melting points were measured using a SGW X-4 micromelting point apparatus and uncorrected. Optical rotations were obtained on a JASCO P-1020 digital polarimeter. UV spectra were recorded on PuXi TU-1810 UV-visible spectrophotometer. IR spectra were taken on a NICOLET 510P FT-IR spectrometer in $\mathrm{KBr}$ discs. NMR spectra were recorded on a Bruker Avance $500\left(500 \mathrm{MHz}\right.$ for ${ }^{1} \mathrm{H}$ and $125 \mathrm{MHz}$ for ${ }^{13} \mathrm{C}$ ) spectrometer using TMS as internal standard and chemical shifts were recorded as $\delta$ values. Mass spectra were measured on VG Auto Spec 3000 mass spectrometer. Semipreparative HPLC was preformed on Dionex HPLC system equipped with P680 HPLC pump, UVD 340U UV-visible photodiode-array detector, and $\mathrm{C}_{18}$ column $(5 \mu \mathrm{m}, 8.0 \times 250 \mathrm{~mm})$. Silica gel $(200 \sim 300$ mesh and $\mathrm{GF}_{254}$ ) for column chromatography (CC) and preparative thin-layer chromatography (P-TLC) were the products of Qingdao Haiyang Chemical Co., Qingdao, China. ODS was the product of Merck Corporation. Sephadex LH-20 was purchased from Pharmacia Corporation. Chloramphenicol, amphotericin B, DPPH ( $\alpha, \alpha$-diphenyl- $\beta$-picrylhydrazyl), and BHT (butylated hydroxytoluene) were purchased from Sigma Corporation.

\section{Microorganism}

Endophytic fungus $A$. niger EN-13 was isolated from the tissue of surface-sterilized marine brown alga $C$. sinuosa that was collected at the Qingdao coastline, China. The fungus was morphologically identified as $A$. niger by one of the authors (Y.Z.) and was preserved in China Center for Type Culture Collection with access number CCTCC AF 206004.

Strains for antimicrobial assay, Escherichia coli (ATCC 9637), Staphylococcus aureus (ATCC 29213), Candida albicans (ATCC 10231), and A. niger (ATCC 6275), were obtained from the stock cultures maintained at the School of Medicine and Pharmacology, the Ocean University of China, Qingdao, China.

\section{Fermentation}

A small spoon of spores growing on malt agar slant was inoculated onto malt agar plate and cultured at $28^{\circ} \mathrm{C}$ for 7 days. Then a piece (size: $4 \mathrm{~cm}^{2}$ ) of mycelium was inoculated into 1000-ml Erlenmeyer flasks each containing $300 \mathrm{ml}$ of culture medium composed of glucose $2.0 \%$, peptone $0.5 \%$, malt extract $0.3 \%$, yeast extract $0.3 \%$, and artificial sea salt $2.44 \%$. The $\mathrm{pH}$ was adjusted to 7.4 before autoclaving. Static fermentation was carried out at $25^{\circ} \mathrm{C}$ for 30 days.

\section{Extraction and Isolation}

The culture broth (30 liters) was filtered through absorbent cotton to separate the mycelia and supernatant. Air-dried mycelia were smashed and extracted with 3 liters of methanol to afford an extract. The supernatant was concentrated in vacuo to about 4 liters, and then extracted three times with ethyl acetate to give an ethyl acetate extract. Since the two extracts displayed similar TLC and HPLC profiles, so they were combined and evaporated under reduced pressure, resulting in a crude extract $(42.0 \mathrm{~g})$.

This extract was first chromatographed on a silica gel (200 300 mesh) column by eluting stepwise from chloroform to methanol. The chloroform - methanol $(80: 1)$ fraction $(6.13 \mathrm{~g})$ was subsequently subjected to a silica gel column eluted in gradient ratios with petroleum ether-acetone and chloroform-methanol consecutively. This afforded three yellowish fractions including fractions I $(880 \mathrm{mg}$, petroleum ether-acetone, $2: 1)$, II $(808$ $\mathrm{mg}$, petroleum ether-acetone $1.5: 1)$, and III $(1.05 \mathrm{~g}$, chloroform - methanol, $30: 1)$. Fraction I was applied on 
Table 1 Physico-chemical properties of $\mathbf{1} \sim \mathbf{3}$

\begin{tabular}{|c|c|c|c|}
\hline & 1 & 2 & 3 \\
\hline Appearance & Yellow powder & Yellow powder & Yellow powder \\
\hline Melting point & $193 \sim 195^{\circ} \mathrm{C}$ & $169 \sim 171^{\circ} \mathrm{C}$ & $222 \sim 224^{\circ} \mathrm{C}$ \\
\hline$[\alpha]_{D}^{20}$ & - & $-15.3^{\circ}$ ( c 0.27, MeOH) & $-11.5^{\circ}$ ( c $\left.0.34, \mathrm{MeOH}\right)$ \\
\hline Molecular formula & $\mathrm{C}_{16} \mathrm{H}_{14} \mathrm{O}_{6}$ & $\mathrm{C}_{32} \mathrm{H}_{30} \mathrm{O}_{12}$ & $\mathrm{C}_{31} \mathrm{H}_{26} \mathrm{O}_{11}$ \\
\hline Molecular weight & 302 & 606 & 574 \\
\hline HR-ESI-MS m/z & {$[\mathrm{M}+\mathrm{Na}]^{+}$} & {$[\mathrm{M}+\mathrm{Na}]^{+}$} & {$[\mathrm{M}+\mathrm{H}]^{+}$} \\
\hline Calcd & 325.0688 & 629.1634 & 575.1553 \\
\hline Found & 325.0681 & 629.1642 & 575.1534 \\
\hline$U V \lambda_{\max }^{\mathrm{MeOH}} \mathrm{nm}(\log \varepsilon)$ & $\begin{array}{l}210 \text { (sh, 4.35), } 226 \text { (4.48), } \\
255 \text { (sh, 4.36), } 276(4.61) \\
325 \text { (3.76), } 400 \text { (3.95) }\end{array}$ & $\begin{array}{l}236 \text { (4.79), } 281 \text { (4.80), } \\
316 \text { (sh, 4.30), } 380 \text { (3.88) }\end{array}$ & $\begin{array}{l}232(4.33), 282(4.63) \\
329(3.82), 403(3.80)\end{array}$ \\
\hline $\mathrm{IR} v_{\max }^{\mathrm{KBr}} \mathrm{cm}^{-1}$ & $\begin{array}{l}3427,2926,2855,1659,1629 \\
1582,1439,1254,1210,1168\end{array}$ & $\begin{array}{l}3433,2934,2844,1660,1613 \\
1405,1238,1165\end{array}$ & $\begin{array}{l}3430,2935,2850,1650,1619 \\
1424,1262,1165\end{array}$ \\
\hline NMR data & Table 2 & Table 3 & Table 4 \\
\hline
\end{tabular}

preparative TLC (pTLC) (silica gel, chloroform - methanol, $40: 1)$ and ODS column $(\mathrm{MeOH})$ to give 1 (1.8 $\mathrm{mg})$; separation of other eluates of fraction I produced $4(62 \mathrm{mg})$, $9(75 \mathrm{mg})$, and $\mathbf{1 0}(39 \mathrm{mg})$, by repeated pTLC and Sephadex LH-20 gel chromatography (chloroform methanol, 1:1). Fraction II gave two subfractions after a CC separation on silica gel (petroleum ether-acetone, $2: 1$ ). One subfraction was further purified by semipreparative HPLC (ODS, methanol - water, $65: 35$ ) and consecutive pTLC to give $8(3 \mathrm{mg})$, and the other subfraction gave $11(20 \mathrm{mg})$ by using of CC on ODS (methanol-water, 85:15) and Sephadex LH-20. Through consecutive $\mathrm{CC}$ on silica gel (petroleum ether-acetone, 18:1; chloroform - methanol, $80: 1$, respectively), Sephadex LH-20 and two times of pTLC (dichloromethane methanol, $40: 1$ and $20: 1$, respectively), $2(20 \mathrm{mg})$ was obtained from fraction III; Compounds $3(30 \mathrm{mg}), \mathbf{5}$ (120 mg), 6 (32 mg), 7 (47 mg), and 12 (28 mg) were also purified from fraction III by repeated CC on silica gel, ODS column, and Sephadex LH-20.

\section{Biological Assay}

In vitro cytotoxic assay to tumor cell lines SMMC-7721 (hepatocellular carcinoma cells) and A549 (human lung epithelial cells) was performed following the SRB method [8]. Antimicrobial assay was performed by using of the well diffusion method [9]. Chloramphenicol and amphotericin $\mathrm{B}$ were used as antibacterial and antifungal controls, respectively. The DPPH radical scavenging activity was determined by the method as previously report [10].

\section{Results and Discussion}

\section{Physico-chemical Properities}

Physico-chemical properties of $\mathbf{1} \sim \mathbf{3}$ are summarized in Table 1. All of them showed the mutual absorptions at $220 \sim 240,275 \sim 285,380 \sim 410 \mathrm{~nm}$ in the UV spectra. In addition, the presence of hydroxyl and conjugated carbonyl groups in each of the molecules were indicated by the absorption bands at $3425 \sim 3435$ and $1650 \sim 1660 \mathrm{~cm}^{-1}$ in the IR spectra, respectively.

\section{Structure Determination}

1 was obtained as yellow powder. Its molecular formula was determined as $\mathrm{C}_{16} \mathrm{H}_{14} \mathrm{O}_{6}$ by HR-ESI-MS, which was in agreement with the ${ }^{1} \mathrm{H}$ and ${ }^{13} \mathrm{C}$ NMR data (Table 2), indicating 10 degrees of unsaturation. The IR spectrum suggested the presence of hydroxyl $\left(3427 \mathrm{~cm}^{-1}\right)$ and conjugated carbonyl $\left(1659 \mathrm{~cm}^{-1}\right)$ groups in the molecule. The ${ }^{13} \mathrm{C}$ NMR and DEPT spectra indicated the presence of 16 carbons in the molecule including one hydroxymethyl group, two methoxy groups, four $s p^{2}$ methines, and nine quaternary $s p^{2}$ carbons (one of which was carbonyl), indicating that the compound to be tricyclic. The ${ }^{1} \mathrm{H}$ NMR spectrum showed signals for one hydroxymethyl $\left(\delta_{\mathrm{H}} 4.54\right.$, $2 \mathrm{H}, \mathrm{d}, J=5.1 \mathrm{~Hz},-\mathrm{CH}_{2} \mathrm{OH} ; \delta_{\mathrm{H}} 4.96,1 \mathrm{H}$, br s, $\left.-\mathrm{CH}_{2} \mathrm{OH}\right)$, two methoxyls $\left(\delta_{\mathrm{H}} 3.91,3.93\right)$, two meta-coupled aromatic protons $\left(\delta_{\mathrm{H}} 6.44\right.$, br s; $\left.\delta_{\mathrm{H}} 6.80, \mathrm{~d}, J=0.8 \mathrm{~Hz}\right)$, two singlet aromatic or olefinic protons $\left(\delta_{\mathrm{H}} 6.28, \mathrm{~s}\right.$ and $\left.\delta_{\mathrm{H}} 7.07, \mathrm{~s}\right)$, and one phenolic hydroxyl proton $\left(\delta_{\mathrm{H}} 14.84\right)$, which was obviously an intramolecular hydrogen-bonded and 
characteristic of linear naphtho- $\gamma$-pyrone structural unit [5, 7]. Detailed analysis of the NMR data suggested that $\mathbf{1}$ was a linear naphtho- $\gamma$-pyrone monomer, structurally related to the reported rubrofusarin $\mathrm{B}$ [11]. However, the 2- $\mathrm{CH}_{3}$ group in rubrofusarin $\mathrm{B}$ was replaced by a $2-\mathrm{CH}_{2} \mathrm{OH}$ group in 1. This was indicated by the fact that the carbon signal for 2- $\mathrm{CH}_{3}$ of rubrofusarin B at $\delta_{\mathrm{C}} 20.4$ disappeared while a hydroxymethyl signal at $\delta_{\mathrm{C}} 61.3$ for 1 was observed in the ${ }^{13} \mathrm{C}$ NMR spectrum. Also in the ${ }^{1} \mathrm{H}$ NMR spectrum the signal for the singlet methyl group in rubrofusarin $\mathrm{B}$ was replaced by a hydroxymethyl group $\left(\delta_{\mathrm{H}} 4.54,2 \mathrm{H},-\mathrm{CH}_{2} \mathrm{OH}\right.$ and $\left.\delta_{\mathrm{H}} 4.96,1 \mathrm{H},-\mathrm{CH}_{2} \mathrm{OH}\right)$ in $\mathbf{1}$. This deduction was further confirmed by the observed HMBC correlations between the hydroxymethyl proton $\left(\delta_{\mathrm{H}} 4.54\right)$ and C-2 $\left(\delta_{\mathrm{C}}\right.$

Table $2{ }^{1} \mathrm{H}$ and ${ }^{13} \mathrm{C}$ NMR data of $\mathbf{1}$ (acetone- $d_{6}$, TMS, $\delta$ in ppm)

\begin{tabular}{|c|c|c|}
\hline No & $\delta_{\mathrm{H}}(\mathrm{J}$ in $\mathrm{Hz})$ & $\delta_{\mathrm{C}}$ \\
\hline 2 & & 171.9 \\
\hline 3 & $6.28(1 \mathrm{H}, \mathrm{s})$ & 105.2 \\
\hline 4 & & 185.2 \\
\hline $4 a$ & & 105.1 \\
\hline 5 & & 162.0 \\
\hline $5 a$ & & 109.0 \\
\hline 6 & & 162.0 \\
\hline 7 & $6.44(1 \mathrm{H}, \mathrm{brs})$ & 98.0 \\
\hline 8 & & 163.0 \\
\hline 9 & $6.80(1 \mathrm{H}, \mathrm{d}, 0.8)$ & 98.8 \\
\hline $9 a$ & & 140.5 \\
\hline 10 & $7.07(1 \mathrm{H}, \mathrm{s})$ & 101.6 \\
\hline $10 a$ & & 154.0 \\
\hline $2-\mathrm{CH}_{2} \mathrm{OH}$ & $4.54(2 \mathrm{H}, \mathrm{d}, 5.1)$ & 61.3 \\
\hline $2-\mathrm{CH}_{2} \mathrm{OH}$ & $4.96(1 \mathrm{H}, \mathrm{br} s)$ & \\
\hline $5-\mathrm{OH}$ & $14.84(1 \mathrm{H}, \mathrm{s})$ & \\
\hline $6-\mathrm{OCH}_{3}$ & $3.93(3 \mathrm{H}, \mathrm{s})$ & 56.2 \\
\hline $8-\mathrm{OCH}_{3}$ & $3.91(3 \mathrm{H}, \mathrm{s})$ & 55.8 \\
\hline
\end{tabular}

171.9) and C-3 ( $\delta_{\mathrm{C}}$ 105.2) (Fig. 2). Based on the above evidences, the structure of $\mathbf{1}$ was determined as 5-hydroxy6,8-dimethoxy-2-hydroxymethyl-4H-naphtho[2,3-b]pyran4-one, which was named as nigerasperone A.

2 was also obtained as yellow powder. Its molecular formula $\mathrm{C}_{32} \mathrm{H}_{30} \mathrm{O}_{12}$ was determined by HR-ESI-MS and ${ }^{1} \mathrm{H}$ and ${ }^{13} \mathrm{C}$ NMR data (Table 3), indicating 18 degrees of unsaturation. The IR spectrum suggested the presence of hydroxyl $\left(3433 \mathrm{~cm}^{-1}\right)$ and conjugated carbonyl $\left(1660 \mathrm{~cm}^{-1}\right)$ groups. The ${ }^{13} \mathrm{C}$ NMR and DEPT spectra displayed the presence of 32 carbons including two methyls, four methoxyls, two $s p^{3}$ methylenes, four $s p^{2}$ methines, two $s p^{3}$ quaternary carbons, and 18 quaternary $s p^{2}$ carbons (two of which were carbonyls), indicating that the compound to be hexacyclic. The ${ }^{1} \mathrm{H}$ NMR spectrum showed signals for two singlet methyls $\left(\delta_{\mathrm{H}} 1.49,6 \mathrm{H}\right)$, four methoxyls $\left(\delta_{\mathrm{H}} 3.59\right.$, $3.59,3.74$, and 3.94), two meta-coupled aromatic protons $\left(\delta_{\mathrm{H}} 6.21, \mathrm{~d}, J=1.8 \mathrm{~Hz}\right.$ and $\left.\delta_{\mathrm{H}} 6.41, \mathrm{~d}, J=1.8 \mathrm{~Hz}\right)$, two singlet aromatic protons $\left(\delta_{\mathrm{H}} 6.86\right.$ and 7.07), two pairs of protons of two methylenes $\left(\delta_{\mathrm{H}} 2.80,2 \mathrm{H}, \mathrm{d}, J=17.3 \mathrm{~Hz}\right.$ and $\delta_{\mathrm{H}} 3.07,2 \mathrm{H}, \mathrm{d}, J=17.3 \mathrm{~Hz}$ ), and two phenolic hydroxyl protons $\left(\delta_{\mathrm{H}} 12.86,2 \mathrm{H}\right)$, which were obviously intramolecularly hydrogen-bonded and characteristic of angular naphtho- $\gamma$-pyrone structural unit $[5,7]$. All these characters indicated that $\mathbf{2}$ was an asymmetric dimer of two angular naphtho- $\gamma$-pyrone monomers. A survey of the literature revealed that $\mathbf{2}$ exhibited highly similar NMR data with that reported for asperpyrone $\mathrm{B}$ [7] except for the differences in the chemical shifts of $\mathrm{C}-2\left(\mathrm{C}-2^{\prime}\right), \mathrm{C}-3$ (C-3'), $\mathrm{C}-4\left(\mathrm{C}-4^{\prime}\right)$, and $2-\mathrm{CH}_{3}\left(2^{\prime}-\mathrm{CH}_{3}\right)$. The oxygenated olefinic carbons $\mathrm{C}-2\left(\delta_{\mathrm{C}} 166.8\right)$ and $\mathrm{C}-2^{\prime}\left(\delta_{\mathrm{C}} 166.5\right)$ in asperpyrone B were replaced by two $s p^{3}$ quaternary carbons $\left(\delta_{\mathrm{C}} 101.1\right)$ in 2 , each of which was obviously connected to two oxygen atoms. Meanwhile, the olefinic carbons $\mathrm{C}-3\left(\delta_{\mathrm{C}} 110.6\right)$ and C-3' $\left(\delta_{\mathrm{C}} 110.3\right)$ in asperpyrone $\mathrm{B}$ were replaced by two saturated methylenes $\left(\delta_{\mathrm{C}} 48.6, \mathrm{C}-3\right.$ and $\left.\mathrm{C}-3^{\prime}\right)$ in 2 . In addition, the carbon signals for the carbonyl groups $\mathrm{C}-4$ and C-4' shifted downfield from $\delta_{\mathrm{C}} 182.9$ and 183.0 (in
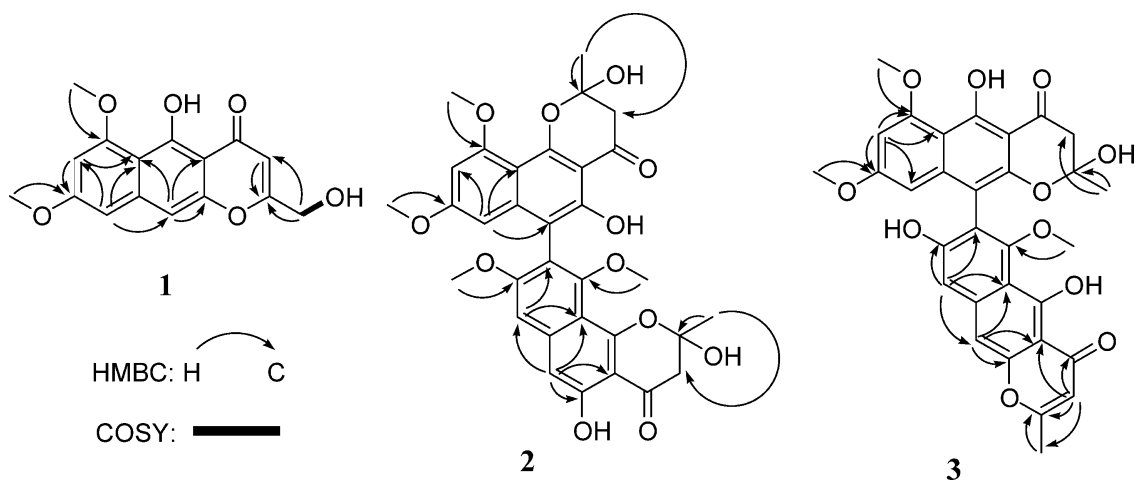

Fig. 2 Selected HMBC and COSY correlations of 1 $\sim \mathbf{3}$. 
Table $3{ }^{1} \mathrm{H}$ and ${ }^{13} \mathrm{C}$ NMR data of 2 (acetone- $d_{6}$, TMS, $\delta$ in ppm)

\begin{tabular}{|c|c|c|c|c|c|}
\hline No & $\delta_{\mathrm{H}}(\mathrm{J}$ in $\mathrm{Hz})$ & $\delta_{\mathrm{C}}$ & No & $\delta_{\mathrm{H}}(\mathrm{J}$ in $\mathrm{Hz})$ & $\delta_{\mathrm{C}}$ \\
\hline 2 & & 101.1 & $2^{\prime}$ & & 101.1 \\
\hline \multirow[t]{2}{*}{3} & $2.80(1 \mathrm{H}, \mathrm{d}, 17.3)$ & 48.6 & $3^{\prime}$ & $2.80(1 \mathrm{H}, \mathrm{d}, 17.3)$ & 48.6 \\
\hline & $3.07(1 \mathrm{H}, \mathrm{d}, 17.3)$ & & & $3.07(1 \mathrm{H}, \mathrm{d}, 17.3)$ & \\
\hline 4 & & 199.0 & $4^{\prime}$ & & 199.0 \\
\hline $4 a$ & & 109.0 & $4^{\prime} \mathrm{a}$ & & 109.4 \\
\hline 5 & & 157.0 & $5^{\prime}$ & & 152.5 \\
\hline 6 & $6.86(1 \mathrm{H}, \mathrm{s})$ & 105.4 & $6^{\prime}$ & & 108.2 \\
\hline $6 a$ & & 141.6 & $6^{\prime} a$ & & 143.9 \\
\hline 7 & $7.07(1 \mathrm{H}, \mathrm{s})$ & 106.4 & $7^{\prime}$ & $6.21(1 \mathrm{H}, \mathrm{d}, 1.8)$ & 98.4 \\
\hline 8 & & 162.0 & $8^{\prime}$ & & 163.0 \\
\hline 9 & & 119.0 & $9^{\prime}$ & $6.41(1 \mathrm{H}, \mathrm{d}, 1.8)$ & 96.6 \\
\hline 10 & & 158.0 & $10^{\prime}$ & & 162.0 \\
\hline $10 a$ & & 108.0 & $10^{\prime} \mathrm{a}$ & & 106.4 \\
\hline $10 \mathrm{~b}$ & & 157.0 & $10^{\prime} \mathrm{b}$ & & 156.2 \\
\hline $2-\mathrm{CH}_{3}$ & $1.49(3 \mathrm{H}, \mathrm{br} \mathrm{s})$ & 28.0 & $2^{\prime}-\mathrm{CH}_{3}$ & $1.49(3 \mathrm{H}, \mathrm{br} \mathrm{s})$ & 28.0 \\
\hline $5-\mathrm{OH}$ & $12.86(1 \mathrm{H}, \mathrm{s})$ & & $5^{\prime}-\mathrm{OH}$ & $12.86(1 \mathrm{H}, \mathrm{s})$ & \\
\hline $8-\mathrm{OCH}_{3}$ & $3.74(3 \mathrm{H}, \mathrm{s})$ & 56.4 & $8^{\prime}-\mathrm{OCH}_{3}$ & $3.59(3 \mathrm{H}, \mathrm{s})$ & 61.6 \\
\hline $10-\mathrm{OCH}_{3}$ & $3.59(3 \mathrm{H}, \mathrm{s})$ & 55.5 & $10^{\prime}-\mathrm{OCH}_{3}$ & $3.94(3 \mathrm{H}, \mathrm{s})$ & 56.3 \\
\hline
\end{tabular}

asperpyrone B) to 199.0 (in 2) because of the lacking of conjugated double bonds in $\mathrm{C}-2$ and $\mathrm{C}-2^{\prime}$. Furthermore, the carbon signals of $2-\mathrm{CH}_{3}$ and $2^{\prime}-\mathrm{CH}_{3}$ shifted to downfield from $\delta_{\mathrm{C}} 20.6$ as in asperpyrone $\mathrm{B}$ to $\delta_{\mathrm{C}} 28.0$ in 2 , while the proton signals of the $2-\mathrm{CH}_{3}$ and $2^{\prime}-\mathrm{CH}_{3}$ shifted upfield from $\delta_{\mathrm{H}} 2.46$ and 2.53 to $\delta_{\mathrm{H}} 1.49$. All these changes revealed that both the $\mathrm{C}-2$ and $\mathrm{C}-2^{\prime}$ double bonds in asperpyrone B were hydrated in $\mathbf{2}$. Thus, the structure of $\mathbf{2}$ was determined as 3,3'-dihydro-2,2',5,5'-tetrahydroxy$8,8^{\prime}, 10,10^{\prime}$-tetramethoxy-2,2' -dimethyl-(6', 9 -bi- $4 H$ naphtho[1,2-b]pyran)-4,4'-dione, which was named as nigerasperone B. Similar to reported 2, 3 (or 2', 3')hydrated naphtho- $\gamma$-pyrones $[5,6, \quad 12 \sim 16]$, the configurations at the chiral centers $\mathrm{C}-2$ and $\mathrm{C}-2$ ' for 2 remained unknown.

3, also obtained as yellow powder, was determined to have the molecular formula to be $\mathrm{C}_{31} \mathrm{H}_{26} \mathrm{O}_{11}$ by HR-ESIMS and ${ }^{1} \mathrm{H}$ and ${ }^{13} \mathrm{C}$ NMR data (Table 4), indicating 19 degrees of unsaturation. The IR spectrum suggested the presence of hydroxyl $\left(3430 \mathrm{~cm}^{-1}\right)$ and conjugated carbonyl $\left(1650 \mathrm{~cm}^{-1}\right)$ groups. The ${ }^{13} \mathrm{C}$ NMR and DEPT spectra displayed 31 carbon signals including two methyls, three methoxyls, one $s p^{3}$ methylene, five $s p^{2}$ methines, one $s p^{3}$ quaternary carbon, and 19 quaternary $s p^{2}$ carbons (two of which were carbonyls), indicating the compound to be hexacyclic. The ${ }^{1} \mathrm{H}$ NMR spectrum showed signals for two singlet methyls $\left(\delta_{\mathrm{H}} 1.54\right.$ and 2.43$)$, three methoxyls $\left(\delta_{\mathrm{H}}\right.$ $3.56,3.59$, and 3.96), two meta-coupled aromatic protons
( $\delta_{\mathrm{H}} 6.20$ and $6.43, \mathrm{~d}, J=1.8 \mathrm{~Hz}$ for each), three singlet aromatic or olefinic protons $\left(\delta_{\mathrm{H}} 6.10,7.12\right.$ and 7.13), a pair of protons of a methylene $\left(\delta_{\mathrm{H}} 2.80\right.$ and $3.07, \mathrm{~d}, J=17.3 \mathrm{~Hz}$ for each), two intramolecularly hydrogen-bonded phenolic hydroxyl protons $\left(\delta_{\mathrm{H}} 14.44\right.$ and 15.03$)$ characteristic of two linear naphtho- $\gamma$-pyrone structural units, and a lonely phenolic hydroxyl proton $\left(\delta_{\mathrm{H}} 12.00\right)[5,7]$. All these signals indicated that 3 was an asymmetric dimer of two linear naphtho- $\gamma$-pyrone monomers, one of which was hydrated at $\mathrm{C}-2^{\prime}$ double bond as suggested by the presence of a $s p^{3}$ methene $\left(\delta_{\mathrm{H}} 2.80,3.07, \mathrm{~d}, J=17.3 \mathrm{~Hz} ; \delta_{\mathrm{C}} 48.6\right)$ and a $s p^{3}$ quaternary carbon $\left(\delta_{\mathrm{C}} 101.3\right)$. The second monomer should be a linear naphtho- $\gamma$-pyrone unit with an $8-\mathrm{OH}$ instead of an $8-\mathrm{OCH}_{3}$, as revealed by the absence of the characteristic signal for $8-\mathrm{OCH}_{3}$ (usually showing a 3-proton singlet at $\delta_{\mathrm{H}} 3.7 \sim 3.8$ and a carbon signal around $\left.\delta_{\mathrm{C}} 56\right)$ and the emergence of the lonely phenolic hydroxyl proton $\left(\delta_{\mathrm{H}} 12.00\right)$ instead. Detailed comparison of the NMR data between 3 and those reported for fonsecinone B [5] showed fairly consistent characteristics except for the substitution of $8-\mathrm{OCH}_{3}\left(\delta_{\mathrm{H}} 3.80\right)$ in fonsecinone B by $8-\mathrm{OH}\left(\delta_{\mathrm{H}} 12.00\right)$ in 3 . From the above evidences discussed, the chemical structure of $\mathbf{3}$ was elucidated as $3^{\prime}$-hydro$2^{\prime}, 5,5^{\prime}, 8$-tetrahydroxy- $6,6^{\prime}, 8^{\prime}$-trimethoxy-2,2' -dimethyl(7,10'-bi-4H-naphtho[2,3-b]pyran)-4,4'-dione, which was named as nigerasperone $\mathrm{C}$.

The structures of $\mathbf{4} \sim \mathbf{1 2}$ were unambiguously elucidated by the analysis of MS and 1D and 2D NMR spectral data 
Table $4{ }^{1} \mathrm{H}$ and ${ }^{13} \mathrm{C}$ NMR data of 3 (acetone- $d_{6}$, TMS, $\delta$ in ppm)

\begin{tabular}{|c|c|c|c|c|c|}
\hline No & $\delta_{\mathrm{H}}(\mathrm{J}$ in $\mathrm{Hz})$ & $\delta_{\mathrm{C}}$ & No & $\delta_{\mathrm{H}}(\mathrm{J}$ in $\mathrm{Hz})$ & $\delta_{\mathrm{C}}$ \\
\hline 2 & & 169.3 & $2^{\prime}$ & & 101.3 \\
\hline \multirow[t]{2}{*}{3} & $6.10(1 \mathrm{H}, \mathrm{s})$ & 107.5 & $3^{\prime}$ & $2.80(1 \mathrm{H}, \mathrm{d}, 17.3)$ & 48.6 \\
\hline & & & & $3.07(1 \mathrm{H}, \mathrm{d}, 17.3)$ & \\
\hline 4 & & 185.3 & $4^{\prime}$ & & 198.9 \\
\hline $4 a$ & & 104.6 & $4^{\prime} \mathrm{a}$ & & 104.6 \\
\hline 5 & & 166.1 & $5^{\prime}$ & & 163.1 \\
\hline $5 a$ & & 111.8 & $5^{\prime} \mathrm{a}$ & & 108.0 \\
\hline 6 & & 159.5 & $6^{\prime}$ & & 163.1 \\
\hline 7 & & 119.2 & $7^{\prime}$ & $6.43(1 \mathrm{H}, \mathrm{d}, 1.8)$ & 96.6 \\
\hline 8 & & 163.1 & $8^{\prime}$ & & 163.4 \\
\hline 9 & $7.12(1 \mathrm{H}, \mathrm{s})$ & 106.3 & $9^{\prime}$ & $6.20(1 \mathrm{H}, \mathrm{d}, 1.8)$ & 98.6 \\
\hline $9 a$ & & 141.5 & $9^{\prime} a$ & & 143.9 \\
\hline 10 & $7.13(1 \mathrm{H}, \mathrm{s})$ & 101.2 & $10^{\prime}$ & & 105.9 \\
\hline $10 a$ & & 153.8 & $10^{\prime} a$ & & 153.8 \\
\hline $2-\mathrm{CH}_{3}$ & $2.43(3 \mathrm{H}, \mathrm{s})$ & 20.6 & $2^{\prime}-\mathrm{CH}_{3}$ & $1.54(3 \mathrm{H}, \mathrm{s})$ & 28.0 \\
\hline $5-\mathrm{OH}$ & $14.44(1 \mathrm{H}, \mathrm{s})$ & & $5^{\prime}-\mathrm{OH}$ & $15.03(1 \mathrm{H}, \mathrm{s})$ & \\
\hline $6-\mathrm{OCH}_{3}$ & $3.56(3 \mathrm{H}, \mathrm{s})$ & 62.0 & $6^{\prime}-\mathrm{OCH}_{3}$ & $3.96(3 \mathrm{H}, \mathrm{s})$ & 56.4 \\
\hline $8-\mathrm{OH}$ & $12.00(1 \mathrm{H}, \mathrm{brs})$ & & $8^{\prime}-\mathrm{OCH}_{3}$ & $3.59(3 \mathrm{H}, \mathrm{s})$ & 55.5 \\
\hline
\end{tabular}

and by comparison with literature reported values [5 7].

\section{Biological Activities}

The in vitro cytotoxic activity assay revealed that none of these compounds showed significant inhibitory activity $\left(\mathrm{IC}_{50}>10 \mu \mathrm{g} / \mathrm{ml}\right)$ against the proliferation of tumour cell lines SMMC-7721 and A549.

3, 5, 8, and 9 exhibited weak inhibitory activity against fungus $C$. albicans in the antimicrobial assay. Compared with the clear inhibition zone (i.d. $12 \mathrm{~mm}$ ) of the positive control amphotericin $\mathrm{B}, \mathbf{3}, \mathbf{5}, \mathbf{8}$, and $\mathbf{9}$ also show visible inhibition zones with the diameter of $9,10,14$, and $9 \mathrm{~mm}$, respectively. Nevertheless, their inhibition zones were fainter. So they were judged to be weakly active.

In the DPPH radical scavenging assay, 3, 5, 10, and $\mathbf{1 2}$ showed moderate activity with scavenging ratios of $41.6 \%$, $48.1 \%, 13.2 \%$, and $37.5 \%$, respectively, at a concentration $50 \mu \mathrm{g} / \mathrm{ml}$, compared to $80.4 \%$ of the positive control, BHT.

Naphtho- $\gamma$-pyrones have been mainly reported from fungi of the genera Fusarium and Aspergillus as well as from some plants $[5,17 \sim 19]$. Compounds of this family were reported to exhibit highly diverse bioactivities, including anticancer, antibacterial, antifungal, anti-signal transduction, antiallergic, and inhibitory activities to HMGCoA reductase, xanthine oxidase and Taq DNA polymerase $[7,20,21]$, revealing their potential prospect for further research and application. In the present report, A. niger EN13 showed high structural diversity of naphtho- $\gamma$-pyrone derivatives.

Acknowledgements This work was financially supported by the National Natural Science Foundation of China (No. 30530080) and by the Department of Science \& Technology of Shandong Province (2006GG2205023). B.-G. W. wishes to acknowledge the Guangdong Key Laboratory of Marine Materia Medica for partial financial support. The authors also wish to acknowledge H.-M. Zhong at Qingdao University of Science and Technology for his valuable help of the work. We would also like to acknowledge the anonymous referees for the critical comments and suggestions to our manuscript.

\section{References}

1. Varoglu M, Corbett TH, Valeriote FA, Crews P. Asperazine, a selective cytotoxic alkaloid from a sponge-derived culture of Aspergillus niger. J Org Chem 62: 7078-7079 (1997)

2. Hiort J, Maksimenka K, Reichert M, Perovic-Ottstadt S, Lin WH, Wray V, Steube K, Schaumann K, Weber H, Proksch P, Ebel R, Muller WEG, Bringmann G. New natural products from the sponge-derived fungus Aspergillus niger. J Nat Prod 67: 1532-1543 (2004)

3. Bugni TS, Abbanat D, Bernan VS, Maiese WM, Greenstein M, Wagoner RMV, Ireland CM. Yanuthones: novel metabolites from a marine isolate of Aspergillus niger. J Org Chem 65: 7195-7200 (2000)

4. Ui H, Shiomi K, Yamaguchi Y, Masuma R, Nagamitsu T, 
Takano D, Sunazuka T, Namikoshi M, Ōmura S. Nafuredin, a novel inhibitor of NADH-fumarate reductase, produced by Aspergillus niger FT-0554. J Antibiot 54: 234-238 (2001)

5. Priestap HA. New naphthopyrones from Aspergillus fonsecaeus. Tetrahedron 40: 3617-3624 (1984)

6. Ehrlich KC, Delucca II AJ, Ciegler A. Naphtho- $\gamma$-pyrone production by Aspergillus niger isolated from stored cottonseed. Appl Environ Microbiol 48: 1-4 (1984)

7. Akiyama K, Teraguchi Y, Hamasaki Y, Mori M, Tatsumi K, Ohnishi K, Hayashi H. New dimeric naphthopyrones from Aspergillus niger. J Nat Prod 66: 136-139 (2003)

8. Skehan P, Storeng R, Scudiero D, Monks A, McMahon J, Vistica D, Warren JT, Bokesch H, Kenney S, Boyd MR. New colorimetric cytotoxicity assay for anticancer-drug screening. J Natl Cancer Inst 82: 1107-1112 (1990)

9. Al-Burtamani SKS, Fatope MO, Marwah RG, Onifade AK, Al-Saidi SH. Chemical composition, antibacterial and antifungal activities of the essential oil of Haplophyllum tuberculatum from Oman. J Ethnopharmacol 96: 107-112 (2005)

10. Duan XJ, Zhang WW, Li XM, Wang BG. Evaluation of antioxidant property of extract and fractions obtained from a red alga, Polysiphonia urceolata. Food Chem 95: 37-43 (2006)

11. Priestap HA. ${ }^{13} \mathrm{C}$ NMR spectroscopy of naphtho- $\gamma$-pyrones. Magn Reson Chem 24: 875-878 (1986)

12. Galmarini OL, Stodola FH. Fonsecin, a pigment from an Aspergillus fonsecaeus Mutant. J Org Chem 30: 112-115 (1965)

13. Tanaka H, Wang PL, Yamada O, Tamura T. Yellow pigments of Aspergillus niger and A. awamori. Part I. Isolation of aurasperone A and related pigments. Agric Biol Chem 30: 107-113 (1966)

14. Galmarini OL, Mastronardi IO, Priestap HA. Two novel metabolites of Aspergillus fonsecaeus. Experientia 30: 586 (1974)

15. Ghosal S, Biswas K, Chakrabarti DK. Toxic naphtho- $\gamma$ pyrones from Aspergillus niger. J Agric Food. Chem 27: 1347-1351 (1979)

16. Bouras N, Mathieu F, Coppel Y, Lebrihi A. Aurasperone F-a new member of the naphtho-gamma-pyrone class isolated from a cultured microfungus, Aspergillus niger C-433. Nat Prod Res 19: 653-659 (2005)

17. Ernst-Russell MA, Chai CLL, Wardlaw JH, Elix JA. Euplectin and coneuplectin, new naphthopyrones from the lichen Flavoparmelia euplecta. J Nat Prod 63: 129-131 (2000)

18. Coelho RG, Vilegas W, Devienne KF, Raddi MSG. A new cytotoxic naphthopyrone dimer from Paepalanthus bromelioides. Fitoterapia 71: 497-500 (2000)

19. Barbosa FG, Oliveira MCF, Braz-Filho R, Silveira ER. Anthraquinones and naphthopyrones from Senna rugosa. Biochem Syst Ecol 32: 363-365 (2004)

20. Song YC, Li H, Ye YH, Shan CY, Yang YM, Tan RX. Endophytic naphthopyrone metabolites are co-inhibitors of xanthine oxidase, SW1116 cell and some microbial growths. FEMS Microbiol Lett 241: 67-72 (2004)

21. Sakurai M, Kohno J, Yamamoto K, Okuda T, Nishio M, Kawano K, Ohnuki T. TMC-256A1 and C1, new inhibitors of IL-4 signal transduction produced by Aspergillus niger var. niger TC 1629. J Antibiot 55: 685-692 (2002) 